\title{
The Current State of Beta-Cell-Mass PET Imaging for Diabetes Research and Therapies
}

\author{
Pierre Cheung *(D) and Olof Eriksson
}

check for updates

Citation: Cheung, P.; Eriksson, O. The Current State of Beta-Cell-Mass PET Imaging for Diabetes Research and Therapies. Biomedicines 2021, 9 1824. https://doi.org/10.3390/ biomedicines 9121824

Academic Editors: Björn Tyrberg and Maria Sörhede Winzell

Received: 5 November 2021

Accepted: 30 November 2021

Published: 3 December 2021

Publisher's Note: MDPI stays neutral with regard to jurisdictional claims in published maps and institutional affiliations.

Copyright: (c) 2021 by the authors. Licensee MDPI, Basel, Switzerland. This article is an open access article distributed under the terms and conditions of the Creative Commons Attribution (CC BY) license (https:/ / creativecommons.org/licenses/by/ $4.0 /)$.
Science for Life Laboratory, Department of Medicinal Chemistry, Uppsala University, SE-75183 Uppsala, Sweden; olof.eriksson@ilk.uu.se

* Correspondence: pierre.cheung@ilk.uu.se

Abstract: Diabetes is a chronic metabolic disease affecting over 400 million people worldwide and one of the leading causes of death, especially in developing nations. The disease is characterized by chronic hyperglycemia, caused by defects in the insulin secretion or action pathway. Current diagnostic methods measure metabolic byproducts of the disease such as glucose level, glycated hemoglobin $(\mathrm{HbA1c})$, insulin or C-peptide levels, which are indicators of the beta-cell function. However, they inaccurately reflect the disease progression and provide poor longitudinal information. Beta-cell mass has been suggested as an alternative approach to study disease progression in correlation to beta-cell function, as it behaves differently in the diabetes physiopathology. Study of the beta-cell mass, however, requires highly invasive and potentially harmful procedures such as pancreatic biopsies, making diagnosis and monitoring of the disease tedious. Nuclear medical imaging techniques using radiation emitting tracers have been suggested as strong non-invasive tools for beta-cell mass. A highly sensitive and high-resolution technique, such as positron emission tomography, provides an ideal solution for the visualization of beta-cell mass, which is particularly essential for better characterization of a disease such as diabetes, and for estimating treatment effects towards regeneration of the beta-cell mass. Development of novel, validated biomarkers that are aimed at beta-cell mass imaging are thus highly necessary and would contribute to invaluable breakthroughs in the field of diabetes research and therapies. This review aims to describe the various biomarkers and radioactive probes currently available for positron emission tomography imaging of beta-cell mass, as well as highlight the need for precise quantification and visualization of the beta-cell mass for designing new therapy strategies and monitoring changes in the beta-cell mass during the progression of diabetes.

Keywords: beta-cell mass; diabetes; positron emission tomography

\section{Human Pancreas}

The human pancreas is an elongated organ situated in the left hypochondriac and epigastric region of the abdomen with a dual exocrine and endocrine function. The majority of the pancreas is composed of exocrine cells ( $98-99 \%)$, which are organized into acini, that release a mixture of digestive enzymes and bicarbonate to help with digestion. On the other hand, the endocrine cells $(\sim 1-2 \%)$ are organized into clusters named islets of Langerhans and dispatched heterogeneously over the pancreas. They are divided into five different cell types (alpha, beta, delta, PP, epsilon), which were discovered through histochemical and immuno-staining. Among them, beta cells account for $\sim 50-80 \%$ of the pancreatic endocrine cell population and are responsible for insulin production. Insulin is a hypoglycemic peptide hormone that plays a major role in maintaining proper glucose metabolism and is tightly linked to pathologies such as diabetes mellitus [1].

\section{Diabetes Mellitus}

Diabetes mellitus also termed "sweet diabetes" or simply diabetes, is a chronic metabolic disease affecting over 400 million people worldwide, and it is one of the leading 
causes of death, especially in developing nations. Diabetes is characterized by chronic hyperglycemia caused by defects in the insulin secretion or action pathway. Common symptoms of diabetes induced hyperglycemia are polyuria (excessive urine production) accompanied by polydipsia (excessive thirst), with long term complications of the disease including ulcers, retinopathy and neuropathy [2]. As diabetes etiology is fairly diverse, the disease has been classified into various subtypes. A non-exhaustive list of them include the following: monogenic defects, gestational, type 1 and type 2 [3].

\subsection{Monogenic Diabetes}

The monogenic form of diabetes is associated with a single gene defect, most often related to insulin secretion pathways. The neonatal form, which includes patients under the age of 6 months, is associated with many methylation abnormalities on the chromosome 6q24 [4], as well as mutations in pancreatic ATP-sensitive potassium channels that are responsible for insulin release [5]. Maturity-onset diabetes of the young (MODY) forms a group comprised of several autosomic dominant disorders that often affect patients under the age of 25. The many MODY variants are defined by their genetic defects and cause symptoms of diabetes with various degrees of severity. Common causes of MODY are genetic defects of GCK (Glucokinase), HNF1A (hepatocyte nuclear factor 1-alpha) and HNF4A (hepatocyte nuclear factor 4-alpha), which are involved in glucose sensing and glycemic regulation [6].

\subsection{Gestational Diabetes}

Gestational diabetes (GDM) is described as the onset of glucose intolerance during pregnancy. This results in significantly increased risks for the mother and fetus of developing diabetes and cardiovascular issues later in life. The incidence of GDM has been increasing through the years with the emergence of a new generation of diabetic childbearing women [7].

\subsection{Type 1 Diabetes}

Type 1 diabetes (T1D) affects $\sim 10 \%$ of the diabetic population and is characterized by the destruction of the insulin-producing beta cells in the pancreatic islets by an immunemediated process, resulting in the disruption of proper glucose regulation. Clear evidence points towards a T-cell-mediated autoimmune process in the destruction of beta-cells [8,9], which is supported by the discovery of several autoantigens, such as GAD65, GAD67 and ICA69, in recent years. Th1 lymphocytes in particular have been demonstrated to be closely associated with T1D pathophysiology through the production of pro-inflammatory cytokines such as IL-4, IL-10 and gamma interferon. Although T-cells have a clear involvement in T1D etiology, B-cells have a less defined role in the development of T1D, with reports suggesting inconsistent humoral activity [10]. Strong genetic risk factors have been identified through associated studies, with strong evidence pointing towards defects in the human leucocyte antigen region (HLA), such as the HLA-DR and HLA-DQ loci [11].

\subsection{Type 2 Diabetes}

The pathophysiology of type 2 diabetes (T2D) is still uncertain; however, it accounts for the majority of diabetes mellitus cases. The main feature that defines type 2 diabetes is insulin resistance, leading to increased insulin production, which can then beget the overload and failure of the pancreatic beta cells. Reactive oxygen species (ROS), for instance, are a byproduct of glucose metabolism from the cellular mitochondria and have been posited to induce beta-cell stress and exhaustion [12]. On the other hand, a high metabolic load can induce the genetic identity loss in beta cells through a dedifferentiation and reprogramming process, leading to beta-cell functional loss [13]. Interestingly, studies involving dieting and bariatric surgery resulted in T2D reversal. These observations gave insights on diabetes etiology after investigating the liver and pancreas during a hypocaloric period. Exposure of the liver to high amounts of triacylglycerol (TAG) or fatty acids, 
induced increased lipid transportation by very low density lipoprotein (VLDL) towards peripheral tissues, including the pancreas. Chronic exposure to those fatty acids can disturb the normal response mechanism of the pancreatic islets to changes in glucose level [14].

\section{The Case for Quantifying Beta Cells}

A common way to diagnose diabetes consists of measuring the activity of beta cells through glucose metabolism indicators such as plasma glucose, glycated hemoglobin (HbA1c), insulin or C-peptide. These indicators provide information on the beta-cell function (BCF) but poorly reflect the beta-cell state. More importantly, they correlate inaccurately with disease progression, especially in the prediabetic phase, as insidious complications due to chronic hyperglycemia could go undetected for many years. Another hallmark of diabetes, beta-cell mass (BCM), has been suggested as a complementary approach to study disease progression as it behaves differently in the pathophysiology of T1D and T2D, in contrast to BCF $[15,16]$. However, contrary to BCF measurements, investigation of the $\mathrm{BCM}$ is restricted as it requires highly invasive and potentially harmful procedures, such as pancreatic biopsies, making diagnosis and monitoring processes tedious. Given the mystery surrounding beta-cell fate during the progression of diabetes within human patients [17], as well as the high BCM variability between individuals [18], there is a clear need for a precise characterization of changes in the BCM to better understand the physiopathology behind the development of the disease [19].

Furthermore, recovery of a functional BCM has been largely described as a viable treatment solution for diabetes [20], meaning that precise quantification and visualization of the BCM would significantly help with designing new therapy strategies by measuring treatment effects and monitoring subsequent changes in the BCM. Islet transplantation, for instance, has been considered for many years as a solution for diabetes reversal, following the loss of insulin producing BCM. Pioneering works by Baker et al. indicated that the liver was an optimal grafting spot for portal vein infusion [21], a method which served as the basis for the now widely accepted Edmonton protocol, which was developed by Shapiro et al. The Edmonton protocol guarantees high successful transplantation rates, while reaching insulin independence with close to normal glycemic control, translating the procedure from an experimental feat to a routine clinical procedure [22]. Excluding auto-transplantations, islet transplantations from donors would, however, require heavy immunosuppressive drugs that would place a heavy burden on the patient and be faced with a widespread shortage of potential donors.

Several renewable cell sources with the potential to differentiate into beta-cell replacements were explored as alternatives [23], starting with the use of human embryonic stem cells (hEScs). The resulting insulin-producing cells were very similar to endogenous beta cells, but had the critical flaw of a poor response to glucose stimulation [24]. New insights were introduced by Kroon et al. after suggesting in vivo functional maturation of stage 4 pancreatic progenitor cells, previously unattainable from in vitro conditions [25]. Lastly, transplantation of differentiated hEScs through a macroencapsulated delivery system allowed protection of the transplants against the host immune system, while maintaining a proper exchange of nutrients, albeit still allowing the maturation process that was necessary to reach production levels that were close to that of native beta-cell hormone levels [26].

Another option is to convert exocrine pancreatic cells into insulin producing cells using transdifferentiation. This technique is based on a reprogramming process via a combined expression of various transcription factors to induce the transition of a differentiated cell into another cell type [27]. Work by Zhou et al. brought to light the role of three critical transcription factors: Ngn3, Pdx1 and Mafa. These three transcription factors are sufficient for in vivo reprogramming of exocrine cells into beta cell-like cells that do not aggregate into islet-like structures, thus are at risk of causing disruption in the normal response to glucose [28].

Regardless of the chosen transplantation method, monitoring transplanted islets remains a hurdle to be overcome, especially during the critical early post-transplantation 
period that dictates graft survivability [29] as it is particularly sensitive to immunosupressive drugs and inflammation stress.

Lastly, accurate and rapid evaluation of novel immunomodulatory therapy methods to curb BCM destruction, such as using pancreatic glutamic acid decarboxylase (GAD) autoantigens administration for an improved T-cell immunity reaction [30-32], or anti-CD3 monoclonal antibodies treatment to stimulate regulatory T-cells activity [33], is challenging without a direct readout of BCM. Thus, reliable methods for in vivo BCM quantification would be a crucial addition to available clinical endpoints in this area of drug development.

\section{In Vivo Quantification of Beta-Cell Mass through Positron Emission Tomography}

Nuclear medicinal imaging techniques using radiation-emitting tracers have been suggested as potential non-invasive tools for the visualization and quantification of BCM. Positron emission tomography (PET), for instance, is based on the detection of two opposite $511 \mathrm{keV}$ photons that follow the annihilation of an electron with a positron emitted from a radioactive probe (Figure 1).

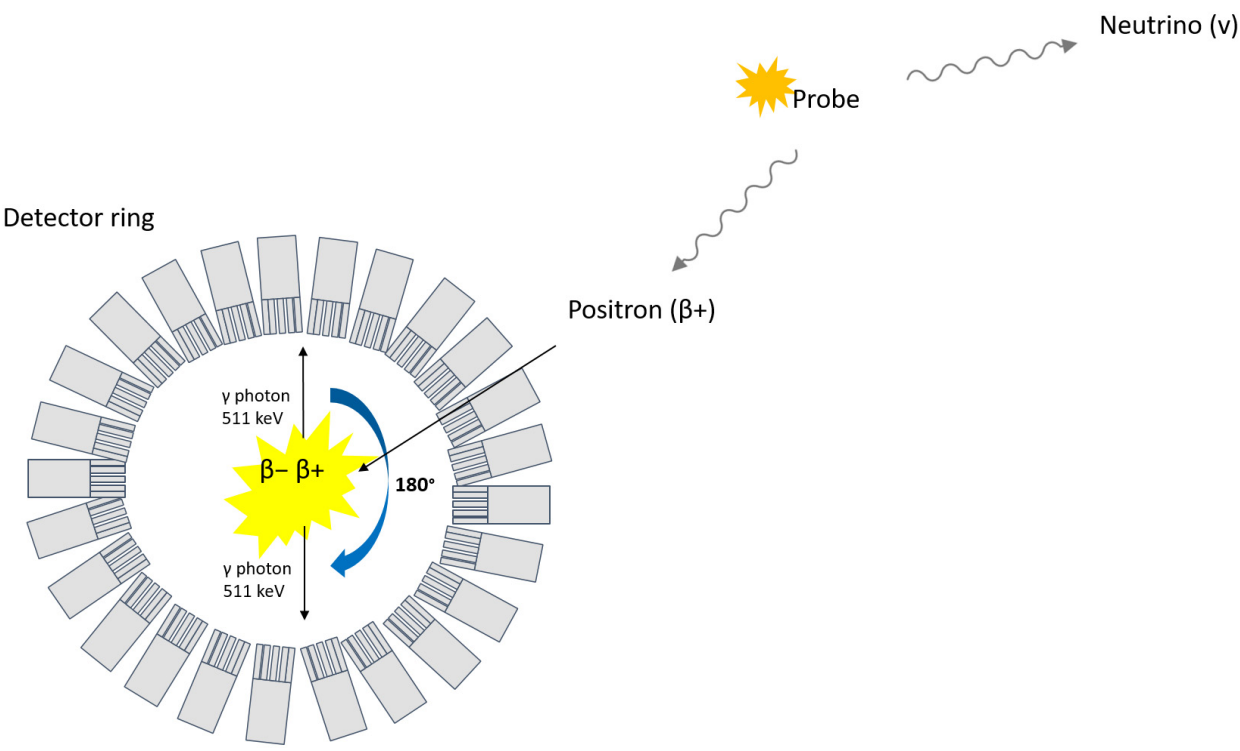

Figure 1. Principle of PET.

Succinctly, PET possesses higher resolution $(\sim 3-5 \mathrm{~mm})$ and better signal quantification compared to other nuclear imaging techniques, such as single photon emission tomography (SPECT) [34]. Both techniques are, however, highly sensitive, meaning low amounts of tracer are enough to allow detection, an important parameter for clinical use to avoid potential adverse pharmacobiological effects. The highly specific uptake of a radioactive tracer within beta cells would usually be represented as being contained in a set of voxels with values reported as concentration (signal/volume) or standardized uptake value (SUV), which can subsequently be represented as hotspots on an image (Figure 2). The signal derived from a virtually perfect tracer for BCM would yield a high specific binding signal coupled with a low background signal that would correlate to a quantitative estimate of the beta-cell density [35].

Although other BCM imaging modalities, such as magnetic resonance imaging (MRI), possess excellent spatial resolution and do not involve any radioactive emission, the MRI signal is not quantifiable in contrast to PET. Moreover, MRI remains highly unspecific and it is not possible to distinguish endocrine and exocrine tissues without the use of potentially toxic paramagnetic contrast agents.

Imaging the pancreatic islets using PET still faces many challenges, notably the small size of the islets $(\sim 20-500 \mu \mathrm{m})$, but also its heterogeneous repartition over the pancreas and the non-uniform microarchitecture. Those restrictions thus require the development 
of highly specific and sensitive imaging targets and probes. Ideally, the generated probe should display a signal many folds higher in endocrine islets compared to exocrine tissues, but also significantly higher than the non-specific signal arising from the surrounding tissues as well as the unbound plasmatic tracer associated with organ perfusion. It is thus a matter of paramount importance to identify a molecular target that is not only selectively expressed on beta cells, but also available for molecular binding to a probe. Several currently studied BCM biomarkers (Figure 3) will be addressed as part of the present review.

\section{A}
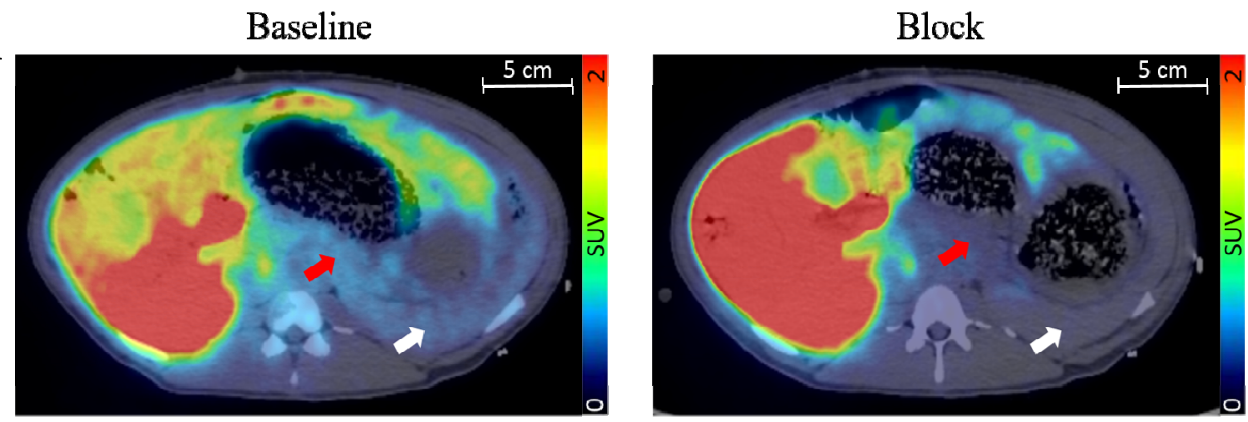

B
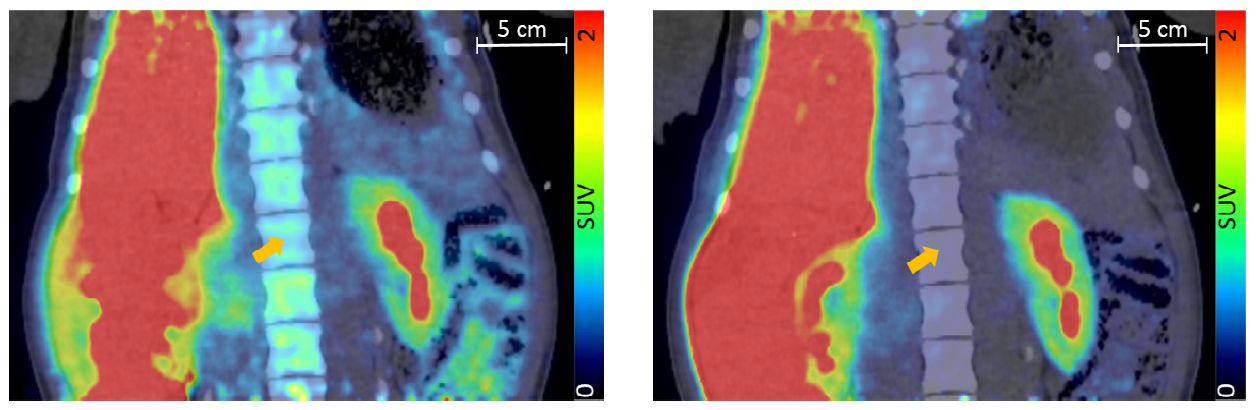

Figure 2. Transversal (A) and coronal view (B) of fused pig PET/CT scan with the averaged signal from 60-90 $\mathrm{min}$. The red arrow indicates the pancreas, the white arrow indicates the spleen, and the orange arrow indicates bone marrow. Adapted with permission from Cheung et al. [36].

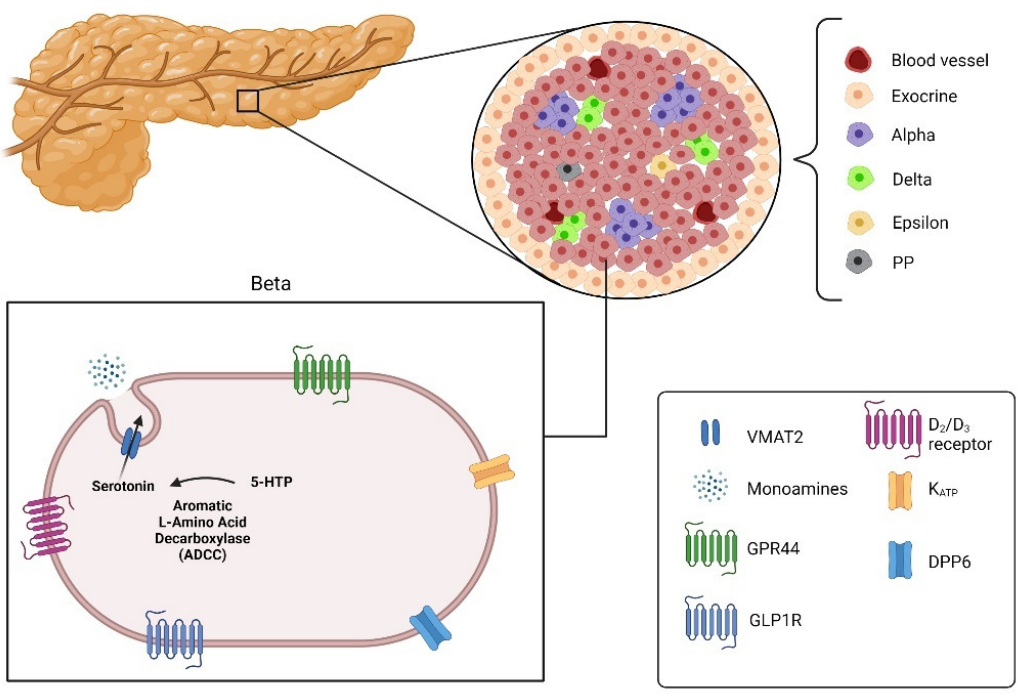

Figure 3. Pancreatic islets divided into alpha, beta, delta, epsilon and pancreatic polypeptide cells (PP) with the targets for imaging beta cells: Vesicular monoamine transporter 2 (VMAT2), G-protein-coupled receptor 44 (GPR44), glucagon-like peptide 1 receptor (GLPIR) and Dipeptidyl peptidase 6 (DPP6) (created with the help of BioRender.com https:/ / biorender.com/ accessed on 31 October 2021). 


\subsection{Glucagon-Like Peptide 1 Receptor}

The glucagon-like peptide 1 receptor (GLP1R) is a therapeutic target for diabetes due to its involvement in insulin release through stimulation of the adenyl cyclase [37], with several GLP1 agonists currently in clinical use. Studies have also showed the role of GLP1R in beta-cell differentiation [38]. Importantly, GLP1R has been reported to be expressed in the human pancreas [39] and confirmed through monoclonal antibody staining [40], leading to extensive studies of the peptide Exendin-4, a GLP1 analogue with better stability, as it is not subject to dipeptidyl peptidase IV degradation [41]. With the increased availability of gallium generators, the radionuclide Gallium- 68 became a widely popular PET radionuclide. Moreover, the half-life of Gallium-68 (68 min) is short enough to not induce a heavy patient burden, a highly appreciated characteristic for clinical translation. Boss et al., for instance, showed through human dosimetry that ${ }^{68}$ Ga-NODAGA-Exendin-4 imaging was likely safe for repeated scans in adults and children, ideal for longitudinal studies [42]. Selvaraju et al. demonstrated non-invasive in vivo imaging of rodent and non-human primates using ${ }^{68} \mathrm{Ga}-\mathrm{DO} 3 \mathrm{~A}-E x e n d i n 4$ [43] with a significant signal uptake in healthy rat pancreases compared to streptozotocin (STZ) induced diabetic rats and a well-defined pancreas in non-human primates. Clinical translation of ${ }^{68} \mathrm{Ga}$-DO3A-Exendin 4 by Eriksson et al. demonstrated the first non-invasive PET quantification of GLP1R in the pancreas of T2D patients, as well as a simplified scanning protocol with improved reproducibility [44].

In parallel, the increasing affordability of cyclotrons points towards Fluorine-18 as the next logical choice for PET imaging, as it offers improved resolution due to its lower energy range, as well as an ideal working half-life (109 min). ${ }^{18} \mathrm{~F}$-Exendin 9-39 was first synthesized by Wang et al. and evaluated in rats. PET images showed, however, low signal uptake in the pancreas compared to the surrounding tissues and no difference between a control and STZ-induced diabetic rats, nor in the spontaneous diabetes BioBreeding diabetes-prone (BB-DP) rat strain [45]. Subsequent work by Kimura et al., using various ${ }^{18}$ F-Exendin 9-39 derivatives, showed increased pancreas to organ ratio in addition to lower liver and kidney uptake using ${ }^{18} \mathrm{~F}-\mathrm{FB} 40-\mathrm{Ex}$ 9-39 in mice [46]. A phase 1 clinical study of ${ }^{18} \mathrm{~F}$-Exendin- 4 by Fujimoto et al. showed a safe dosimetry profile with no adverse events. The pancreas could be clearly visualized with a pancreatic SUV higher than the surrounding GLP1R non expressing tissues. BCM prediction was however not investigated, warranting further investigations [47]. GLP1R has also been reported as a promising marker for insulinoma [48,49], but will not be the subject of this review.

Despite the aforementioned promising results, GLP1R as a biomarker for BCM imaging has also several shortcomings. Given the beneficial effect of the GLP1 signaling on insulin secretion and the maintenance of beta cells in response to glucose level [50], GLP1R expression is subject to variation depending on the metabolic state [51], posing a liability in the value of GLP1R as a biomarker for BCM. Reports also showed significant uptake in alpha cells [52] and the exocrine pancreas [53], although this statement is still very much under debate [54]. Lastly, species variations of GLP1R make the lack of reliable animal models difficult for subsequent probe development [55].

\subsection{Monoamine Receptor}

Vesicular monoamine transporter (VMAT) is an active membrane transporter protein playing an important role in the uptake of vesicles containing monoamines, such as dopamine, adrenaline, histamine and serotonin [56]. The expression profile of the two isoforms (VMAT1 and VMAT2) has been studied and reported in tissues such as the central nervous system, the autonomic nervous system and the neuroendocrine cell system. The expression pattern is mostly mutually exclusive in the given tissue, with VMAT2 expressed exclusively in the beta cells of the endocrine pancreas [57]. Dihydrotetrabenazine (DTBZ) is a well-known analog of the FDA-approved tetrabenazine (TBZ), a monoamine depleter drug used for movement disorder treatment [58]. As such, the positron emitter radioligand ${ }^{18}$ F-FP-DTBZ (also known as ${ }^{18} \mathrm{~F}-\mathrm{AV}-133$ ) has been used to characterize BCM. Normandin et al. provided early clinical trial data using ${ }^{18} \mathrm{~F}-\mathrm{DTBZ}$ for in vivo T1D with a good cor- 
relation to insulin during disease progression, supplied by validation data from kinetic modeling using arterial signal as input functions [59]. Cline et al. showed that in vivo VMAT2 decrease in the whole pancreas (body and tail) was correlated with BCF in long term T2D patients, showing the underlying link between BCM loss and glycemic control deficiency [60]. Results were further supported by Saisho et al., who again demonstrated the correlation between VMAT2 and insulin expression in healthy and diabetic patients; VMAT2-negative but insulin-positive cells could be observed, but this was attributed to the expression polarity of VMAT2 cellular localization [61].

A glaring weakness of using VMAT2 as a target for imaging is the noted expression in pancreatic polypeptide (PP) cells of the endocrine pancreas, warranting caution when interpreting results, as the observed signal uptake of ${ }^{18} \mathrm{~F}-\mathrm{FP}-\mathrm{DTBZ}$ could possibly be the result of non-specific binding [62]. Lack of an appropriate reference tissue heavily hinders the possibility of estimating the non-specific binding signal. Naganawa et al. came up with a suggestion for quantifying non-specific binding using the low stereospecific affinity inactive enantiomer of ${ }^{18}$ F-FP-DTBZ, by scaling the computed non-specific binding potential spleen value to accurately estimate non-specific signal uptake in the pancreas [63]. Given the overlapping presence of receptors and transporters in neural tissues and endocrine pancreas, Bini et al. cross-referenced currently available brain radioligands with a beta-cell gene atlas before going through a human screening. The process resulted in the carbon11 dopamin D2/D3 receptor agonist radioligand ${ }^{11} \mathrm{C}-4$-propyl-9-hydroxynaphthoxazine (PHNO) [64]. Follow-up work by the same research group, using ${ }^{11} \mathrm{C}-\mathrm{PHNO}$ on a cohort of healthy controls and T1D using region comparison kinetic modeling, showed that a short 30 min scan and the SUVR-1 parameter could provide quantitative measurement of the BCM. High amounts of radiometabolites could potentially be a source of confounding signal, but longer scanning time suggested the unlikeliness of the issue; however, it highlighted the importance of a validated reference tissue when using kinetic modeling if arterial blood sampling is to be bypassed [65].

\subsection{GPR44}

Recent proteomics and transcriptomics from Lindskog et al. identified a new transmembrane G-protein-coupled receptor GPR44 (also known as CRTH2, PTGDR2, or CD294) posited as a promising biomarker for BCM monitoring [66]. GPR44 has been reported to be highly expressed in beta cells of the human pancreas or other large animals, such as non-human primates and pigs, but not in the exocrine nor other endocrine tissues of the pancreas [67]. Activation of the GPR44 signaling pathway was assumed to inhibit insulin secretion, but oral administration of a GRP44 inhibitor showed no major impact on insulin secretion in patients with type 2 diabetes [68], albeit demonstrated improvement of islet function under inflammatory and hyperglycemic stress [69]. Inhibition of GPR44 has been well studied in inflammatory processes responsible for allergy and asthma [70], leading to the development of numerous GPR44 antagonists for the treatment of asthma and other allergic diseases, some of them even reaching late clinical phase drug development [71]. Radiolabeled small molecule GPR44 antagonist AZ12204657 with carbon-11 before evaluation in vitro and in vivo by PET, showed great promise regarding visualization and quantification of BCM [72,73]. MK7246 is a GPR44 antagonist originally developed to treat respiratory diseases [74] and is reported to selectively bind to GPR44 in a reversible manner with high affinity and good pharmacokinetic properties [75]. Initial preclinical evaluation of ${ }^{11} \mathrm{C}-\mathrm{MK} 7246$ by Eriksson et al. and Cheung et al. demonstrated a clear binding of ${ }^{11} \mathrm{C}-\mathrm{MK} 7246$ to GPR44 through a receptor/ligand binding mechanism, as the signal uptake could be saturated with non-radioactive MK7246. The optimal biodistribution window for ${ }^{11} \mathrm{C}-\mathrm{MK} 7246$ was discovered to be between $60-90 \mathrm{~min}$ after the hepato-biliary excretion of the radiopharmaceutical compound, revealing a well-defined pancreas on the pig images with no spillover from adjacent tissues [36,76]. Furthermore, an important feature of MK7246 is the presence of a fluorine atom which can thus theoretically be labeled 
with fluorine-18, a radioactive nuclide with lower energy range; thus, allowing greater resolution and will likely be the subject of future studies.

\subsection{Potassium Channels}

ATP-sensitive potassium channels $\left(\mathrm{K}_{\mathrm{ATP}}\right)$ have been long discovered within the human pancreatic beta cells [77-79] and play a major role in membrane depolarization-induced insulin secretion [80]. The pancreatic $\mathrm{K}_{\mathrm{ATP}}$ is composed of multiple subunits, among them is the sulfonylurea receptor 1 (SUR1), which contains the binding site for sulfonylrurea ligand [81]. SUR1 has been suggested as potential biomarker for pancreatic islets [82], with many SUR1 targeting selective pharmaceutical small molecules currently available on the market [83]. Among them, the well-known FDA approved drug glibenclamide (also called glyburide) for T2D treatment [84], a SUR1 selective antagonist that has been extensively studied as potential surface marker for pancreatic endocrine cells with promising results $[85,86]$. However, Schneider et al. raised the question as to whether glibenclamide and its fluorinated derivatives are suitable for BCM imaging, despite showing promising SUR1 binding potential and affinity. Indeed, a poor signal-to-noise ratio, due to plasma protein binding and possibly attributed to poor lipophilicity of the molecule, has been reported [87]. The same group suggested, however, a glibenclamide glucose-conjugate as a substitute to improve hydrophilicity and a better biodistribution pattern [88].

\subsection{Serotonin Synthesis Pathway}

Serotonin is best known as a neurotransmitter for its role in mood regulation. However, pancreatic beta cells have been showed to be able to synthesize and secrete serotonin as well, most likely due to a shared embryogenesis process between neural and pancreatic endocrine tissues [89], with detailed reports mentioned in the literature describing the role of beta-cell intracellular serotonin production and secretion on glycemic control [90,91]. The uptake pattern of serotonin's direct precursor 5-Hydroxytryptophan (5-HTP), is characterized by fast tissue uptake followed by fast wash out, unless it is further metabolized following the classical intracellular serotonin synthesis pathway [92]. This implies that cellular retention of 5-HTP requires serotonin synthesis machinery present in the islet cells, but absent in the exocrine cells [93]. Carbon-11 labeled ${ }^{11} \mathrm{C}-5-\mathrm{HTP}$ has therefore been explored as a potential non-invasive in vivo tracer for quantitative variation in pancreatic islets, with results indicating a clear correlation between ${ }^{11} \mathrm{C}-5-\mathrm{HTP}$ cellular retention and the number of pancreatic islets [94,95]. A longitudinal assessment of pancreatic islets in T1D patients using ${ }^{11} \mathrm{C}-5$-HTP by Espes et al. gave new insights on endocrine pancreas volume variations during T1D disease progression right after disease onset [96]. Considering the ${ }^{11} \mathrm{C}-5$-HTP uptake signal as representative of the endocrine pancreas, the group observed a poor correlation between pancreatic volume and BCF measured through $\mathrm{C}$-peptide and $\mathrm{HbA} 1 \mathrm{c}$ levels. The finding goes, however, against the mainstream postulate suggesting major beta-cell destruction within the 2-year period following diagnosis of T1D. Although the signal from ${ }^{11} \mathrm{C}-5-\mathrm{HTP}$ is unlikely to be from exocrine tissues, signal uptake is an approximation of $\mathrm{BCM}$ as the signal represents overall endocrine pancreatic islets composed by a majority of beta cells. Further studies using beta-cell-specific PET tracers are thus needed to enable direct assessment of BCM.

\subsection{Dipeptidyl Peptidase 6}

Dipeptidyl peptidase 6 (DPP6) is a protein discovered through transcriptomic studies of the human BCM by Eizirik et al. as a membrane surface marker [97]. Subsequently, Balhuizen et al. developed a nanobody, a small peptide $(\sim 13 \mathrm{kDa})$ derivative from homodimeric heavy chain antibodies, and managed to image insulin-producing EndoC- $\beta \mathrm{H} 1$ transplanted mice using SPECT/CT with ${ }^{99} \mathrm{~m}$ Tc-4hD29 [98]. Demine et al. later on developed a camelid nanobody $4 \mathrm{hD} 29$, labelled with gallium-68 that was suitable for PET imaging by conjugation with NCS-NOTA. Results showed good uptake in nude mice transplanted with human pancreatic islets grafts and were validated as a proof of concept 
using Kelly cells, a DPP6 positive neuronal cell line [99]. It is important to emphasize that the above mentioned studies were all based on imaging a high number of transplanted cells in a relatively small volume, which would possibly not be replicable in actual endocrine pancreatic cells dispatched heterogeneously over the pancreas. Another limitation of targeting DPP6 is the expression within beta and alpha cells. On the other hand, reports suggest an overall decrease in alpha-cell populations and function in T1D patients [100], making $4 \mathrm{hD} 29$ still a valuable BCM targeting probe.

\section{Conclusions}

Visualization and quantification of BCM is still a much-debated topic with strongly divided views. Alavi and Werner, for instance, describe the limitation of PET and the structural requirement of the imaging target, along with the aim of BCM imaging, as "futile". Indeed, the feasibility of PET pancreatic imaging is heavily limited due to several restrictions that could be summarized as: (1) biological size of beta cells that are much below the resolution obtainable by current PET scanners; (2) variations in the pancreatic volumes in T1D and T2D patients that would invalidate BCM quantification as a signal to volume ratio; (3) a necessity to clearly distinguish specific binding signal from the non-specific signal that could arise from the vastly predominant exocrine pancreatic tissue; (4) high variability in blockade studies with the presence of residual uptake in diabetes subjects; and (5) lack of promising results from ex vivo autoradiography results [101].

On the other hand, Gotthardt et al. argue that spatial resolution is not the end goal for BCM imaging, as the high sensitivity of PET technology would instead allow the detection of a highly specific signal from the beta-cell population from the metabolic trapping of the tracer, in contrast to a low background signal from the exocrine tissue. The idea would be to rely on a proof of concept, highly specific tracer binding to pancreatic islets and to quantify the large, relative to voxel size, organ of interest (i.e., the pancreas) [102].

As progress in the PET imaging modality is highly restricted by technological advance in the field, future research should be focused on large in silico screenings for novel $\mathrm{BCM}$ restricted biomarkers, in addition to computational design of new imaging probes with strong molecular binding affinities, biodistribution kinetics and adequate systemic clearance properties. Regardless, progress in the field of BCM imaging has seen huge advancements in recent years, highlighted by the many tracers explored in the field (Table 1), with increasing probability to eventually reach the human clinical stage.

Table 1. List of targets for PET BCM imaging and the corresponding available probes.

\begin{tabular}{|c|c|c|c|c|}
\hline Target & Target Limitations & Radioactive Probe & Tested Models & Reference \\
\hline GLP1R & $\begin{array}{l}\text { Expressed in ductal } \\
\text { and exocrine tissues } \\
\text { Species variations } \\
\text { Expression level } \\
\text { depend on metabolic } \\
\text { state }\end{array}$ & $\begin{array}{l}\text { 68Ga-NODAGA- } \\
\text { Exendin-4 } \\
\text { 68Ga-DO3A-Exendin4 } \\
\text { 18F-FB40-Ex 9-39 } \\
\text { 18F-FB(ePEG12)12- } \\
\text { exendin-4 }\end{array}$ & $\begin{array}{l}\text { In Vivo (human) } \\
\text { In Vivo (rodent, non } \\
\text { human p, human) } \\
\text { In Vivo (mice) } \\
\text { In Vivo (human) }\end{array}$ & $\begin{array}{l}\text { Boss et al. [42] } \\
\text { Selvaraju et al. [43]; } \\
\text { Eriksson et al. [44] } \\
\text { Wang et al. [45]; } \\
\text { Kimura et al. [46] } \\
\text { Fujimoto et al. [47] }\end{array}$ \\
\hline VMAT2 & $\begin{array}{c}\text { Expression in } \\
\text { pancreatic polypeptide } \\
\text { cells } \\
\text { Lack of reference tissue }\end{array}$ & 18F-DTBZ & In Vivo (human) & $\begin{array}{l}\text { Normandin et al. [59]; } \\
\text { Cline et al. [60]; } \\
\text { Naganawa et al. [63] }\end{array}$ \\
\hline Dopamine receptor & $\begin{array}{l}\text { Rapid metabolism of } \\
\text { propyl- } \\
\text { hydroxynaphthoxazine } \\
\text { leading to limited } \\
\text { tracer uptake } \\
\text { Difficulties in } \\
\text { differentiating specific } \\
\text { and non specific signal }\end{array}$ & 11C-PHNO & In Vivo (human) & Bini et al. [64] \\
\hline
\end{tabular}


Table 1. Cont.

\begin{tabular}{|c|c|c|c|c|}
\hline Target & Target Limitations & Radioactive Probe & Tested Models & Reference \\
\hline GPR44 & $\begin{array}{l}\text { Lack of reliable in vivo } \\
\text { model expressing } \\
\text { G-protein-coupled } \\
\text { receptor } 44 \text { Not yet } \\
\text { tested in human }\end{array}$ & $\begin{array}{c}\text { 11C-AZ12204657 } \\
\text { 11C-MK7246 }\end{array}$ & $\begin{array}{c}\text { In Vitro; In Vivo } \\
\text { In Vitro (CHO-K1 cells); } \\
\text { In Vivo (Pig) }\end{array}$ & $\begin{array}{l}\text { Jahan et al. [72]; } \\
\text { Eriksson et al. [73] } \\
\text { Eriksson et al. [76]; } \\
\text { Cheung et al. [36] }\end{array}$ \\
\hline SUR1 & $\begin{array}{l}\text { Poor signal-to-noise } \\
\text { ratio }\end{array}$ & 18F-Glibenclamide & $\begin{array}{l}\text { In Vitro (rat islets); In } \\
\text { Vivo (human) }\end{array}$ & Schneider et al. $[87,88]$ \\
\hline Serotonin & $\begin{array}{c}\text { Not a membrane } \\
\text { receptor so more } \\
\text { indicative of beta-cell } \\
\text { function than beta-cell } \\
\text { mass }\end{array}$ & 11C-5-HTP & In Vivo human & $\begin{array}{c}\text { Eriksson et al. [92,94]; } \\
\text { Lubberink et al. [95]; } \\
\text { Espes et al. [96] }\end{array}$ \\
\hline$D P P 6$ & $\begin{array}{l}\text { Expression within } \\
\text { alpha-cells } \\
\text { Not yet tested in } \\
\text { human }\end{array}$ & $68 \mathrm{Ga}-4 \mathrm{hD} 29$ & $\begin{array}{l}\text { In Vivo (transplanted } \\
\text { grafts EndoC- } \beta \mathrm{H} 1 \text { and } \\
\text { human islets into nude } \\
\text { mice) }\end{array}$ & $\begin{array}{l}\text { Balhuizen et al. [98]; } \\
\text { Demine et al. [99] }\end{array}$ \\
\hline
\end{tabular}

Author Contributions: P.C. wrote the manuscript and O.E. edited the manuscript. All authors have read and agreed to the published version of the manuscript.

Funding: This research was funded by the Uppsala Diabetes Center (UDC), Science for Life Laboratory, Diabetes Wellness (\#2409), JDRF (1-SRA-2020-973-S-B), Diabetesfonden, Barndiabetesfonden, the Swedish Research Council (2020-02312), the EFSD/Lilly European Diabetes Research Programme, ExoDiab, the Family Ernfors Foundation and the Nils Erik Holmstens Foundation.

Institutional Review Board Statement: Not applicable.

Informed Consent Statement: Not applicable.

Data Availability Statement: Not applicable.

Conflicts of Interest: Olof Eriksson is an employee of Antaros Medical AB and a co-founder of Antaros Tracer AB. Otherwise, the authors declare that they have no competing interests.

\section{References}

1. Islam, M.S. The Islets of Langerhans; Preface; Advances in Experimental Medicine and Biology; Springer: Berlin, Germany, 2010; Volume 654, pp. vii-viii. ISBN 9789048132706.

2. Warren, R.E.; Deary, I.J.; Frier, B.M. The symptoms of hyperglycaemia in people with insulin-treated diabetes: Classification using principal components analysis. Diabetes Metab. Res. Rev. 2003, 19, 408-414. [CrossRef]

3. Diabetes, D.O.F. Diagnosis and Classi fi cation of Diabetes Mellitus. Diabetes Care 2013, 36, 67-74. [CrossRef]

4. Okuno, M.; Yorifuji, T.; Kagami, M.; Ayabe, T.; Urakami, T.; Kawamura, T.; Kikuchi, N.; Yokota, I.; Kikuchi, T.; Amemiya, S.; et al. Chromosome 6q24 methylation defects are uncommon in childhood-onset non-autoimmune diabetes mellitus patients born appropriate- or large-for-gestational age. Clin. Pediatr. Endocrinol. 2016, 25, 99-102. [CrossRef]

5. Hattersley, A.T.; Patel, K.A. Precision diabetes: Learning from monogenic diabetes. Diabetologia 2017, 60, 769-777. [CrossRef]

6. Yamagata, K.; Oda, N.; Kaisaki, P.J.; Menzel, S.; Furuta, H.; Vaxillaire, M.; Southam, L.; Cox, R.D.; Lathrop, G.M.; Boriraj, V.V.; et al. Mutations in the hepatocyte nuclear factor- $1 \alpha$ gene in maturity-onset diabetes of the young (MODY3). Nature 1996, 384, 455-458. [CrossRef]

7. Mirghani Dirar, A.; Doupis, J. Gestational diabetes from A to Z. World J. Diabetes 2017, 8, 489-511. [CrossRef]

8. Coppieters, K.T.; Dotta, F.; Amirian, N.; Campbell, P.D.; Kay, T.W.H.; Atkinson, M.A.; Roep, B.O.; von Herrath, M.G. Demonstration of islet-autoreactive CD8 T cells in insulitic lesions from recent onset and long-term type 1 diabetes patients. J. Exp. Med. 2012, 209, 51-60. [CrossRef]

9. Terrazzano, G.; Bruzzaniti, S.; Rubino, V.; Santopaolo, M.; Palatucci, A.T.; Giovazzino, A.; La Rocca, C.; de Candia, P.; Puca, A.; Perna, F.; et al. Type 1 diabetes progression is associated with loss of CD3+CD56+ regulatory T cells that control CD8+ T-cell effector functions. Nat. Metab. 2020, 2, 142-152. [CrossRef]

10. Roep, B.O. The role of T-cells in the pathogenesis of Type 1 diabetes: From cause to cure. Diabetologia 2003, 46, 305-321. [CrossRef]

11. Redondo, M.J.; Fain, P.R.; Eisenbarth, G.S. Genetics of type 1A diabetes. Recent Prog. Horm. Res. 2001, 56, 69-89. [CrossRef] 
12. Swisa, A.; Glaser, B.; Dor, Y. Metabolic stress and compromised identity of pancreatic beta cells. Front. Genet. 2017, 8, 21. [CrossRef]

13. Talchai, C.; Xuan, S.; Lin, H.V.; Sussel, L.; Accili, D. Pancreatic $\beta$ cell dedifferentiation as a mechanism of diabetic $\beta$ cell failure. Cell 2012, 150, 1223-1234. [CrossRef]

14. Taylor, R. Type 2 diabetes: Etiology and reversibility. Diabetes Care 2013, 36, 1047-1055. [CrossRef]

15. Chen, C.; Cohrs, C.M.; Stertmann, J.; Bozsak, R.; Speier, S. Human beta cell mass and function in diabetes: Recent advances in knowledge and technologies to understand disease pathogenesis. Mol. Metab. 2017, 6, 943-957. [CrossRef]

16. Weir, G.C.; Gaglia, J.; Bonner-Weir, S. Inadequate $\beta$-cell mass is essential for the pathogenesis of type 2 diabetes. Lancet Diabetes Endocrinol. 2020, 8, 249-256. [CrossRef]

17. Oram, R.A.; Sims, E.K.; Evans-Molina, C. Beta cells in type 1 diabetes: Mass and function; sleeping or dead? Diabetologia 2019, 62, 567-577. [CrossRef]

18. Rahier, J.; Guiot, Y.; Goebbels, R.M.; Sempoux, C.; Henquin, J.C. Pancreatic $\beta$-cell mass in European subjects with type 2 diabetes. Diabetes Obes. Metab. 2008, 10, 32-42. [CrossRef] [PubMed]

19. Kang, N.Y.; Soetedjo, A.A.P.; Amirruddin, N.S.; Chang, Y.T.; Eriksson, O.; Teo, A.K.K. Tools for Bioimaging Pancreatic $\beta$ Cells in Diabetes. Trends Mol. Med. 2019, 25, 708-722. [CrossRef] [PubMed]

20. Remedi, M.S.; Emfinger, C. Pancreatic $\beta$-cell identity in diabetes. Diabetes Obes. Metab. 2016, 18, 110-116. [CrossRef]

21. Barker, C.F. Transplantation of the islets of Langerhans and the histocompatibility of endocrine tissue. Diabetes 1975, $24,766-775$. [CrossRef]

22. Shapiro, A.J.; Lakey, J.R.; Ryan, E.A.; Korbutt, G.S.; Toth, E.; Warnock, G.L.; Kneteman, N.M.; Rajotte, R.V. Islet Transplantation in Seven Patients with Type 1 Diabetes Mellitus Using a Glucocorticoid-Free Immunosuppressive Regimen. N. Engl. J. Med. 2000, 343, 230-238. [CrossRef]

23. Domínguez-Bendala, J.; Lanzoni, G.; Klein, D.; Álvarez-Cubela, S.; Pastori, R.L. The Human Endocrine Pancreas: New Insights on Replacement and Regeneration. Trends Endocrinol. Metab. 2016, 27, 153-162. [CrossRef]

24. D’Amour, K.A.; Bang, A.G.; Eliazer, S.; Kelly, O.G.; Agulnick, A.D.; Smart, N.G.; Moorman, M.A.; Kroon, E.; Carpenter, M.K.; Baetge, E.E. Production of pancreatic hormone-expressing endocrine cells from human embryonic stem cells. Nat. Biotechnol. 2006, 24, 1392-1401. [CrossRef]

25. Kroon, E.; Martinson, L.A.; Kadoya, K.; Bang, A.G.; Kelly, O.G.; Eliazer, S.; Young, H.; Richardson, M.; Smart, N.G.; Cunningham, J.; et al. Pancreatic endoderm derived from human embryonic stem cells generates glucose-responsive insulin-secreting cells in vivo. Nat. Biotechnol. 2008, 26, 443-452. [CrossRef]

26. Motté, E.; Szepessy, E.; Suenens, K.; Stangé, G.; Bomans, M.; Jacobs-Tulleneers-Thevissen, D.; Ling, Z.; Kroon, E.; Pipeleers, D. Composition and function of macroencapsulated human embryonic stem cell-derived implants: Comparison with clinical human islet cell grafts. Am. J. Physiol.-Endocrinol. Metab. 2014, 307, E838-E846. [CrossRef]

27. Sisakhtnezhad, S.; Matin, M.M. Transdifferentiation: A cell and molecular reprogramming process. Cell Tissue Res. 2012, 348, 379-396. [CrossRef]

28. Zhou, Q.; Brown, J.; Kanarek, A.; Rajagopal, J.; Melton, D.A. In vivo reprogramming of adult pancreatic exocrine cells to $\beta$-cells. Nature 2008, 455, 627-632. [CrossRef]

29. Davalli, A.M.; Scaglia, L.; Zangen, D.H.; Hollister, J.; Bonner-weir, S.; Weir, G.C. Vulnerability of Islets in the Immediate Posttrasnplantation Period. Diabetes 1996, 19, 1161-1167. [CrossRef]

30. Tisch, R.; Yang, X.D.; Singer, S.M.; Liblau, R.S.; Fugger, L.; McDevitt, H.O.; Cooke, A.; Mandel, T.E. Immune response to glutamic acid decarboxylase correlates with insulitis in non-obese diabetic mice. J. Endocrinol. Investig. 1994, 17, 586-593. [CrossRef]

31. Kaufman, D.L.; Clare-Salzler, M.; Tian, J.; Forsthuber, T.; Ting, G.S.; Robinson, P.; Atkinson, M.A.; Sercarz, E.E.; Tobin, A.J.; Lehmann, P.V. Spontaneous loss of T-cell tolerance to glutamic acid decarboxylase in murine insulin-dependent diabetes. Nature 1993, 366, 69-72. [CrossRef]

32. Pleau, J.M.; Fernandez-Saravia, F.; Esling, A.; Homo-Delarche, F.; Dardenne, M. Prevention of autoimmune diabetes in nonobese diabetic female mice by treatment with recombinant glutamic acid decarboxylase (GAD 65). Clin. Immunol. Immunopathol. 1995, 76, 90-95. [CrossRef]

33. Chatenoud, L.; Thervet, E.; Primo, J.; Bach, J.F. Anti-CD3 antibody induces long-term remission of overt autoimmunity in nonobese diabetic mice. Proc. Natl. Acad. Sci. USA 1994, 91, 123-127. [CrossRef]

34. Ritt, P.; Vija, H.; Hornegger, J.; Kuwert, T. Absolute quantification in SPECT. Eur. J. Nucl. Med. Mol. Imaging 2011, 38, 69-77. [CrossRef]

35. Eriksson, O.; Laughlin, M.; Brom, M.; Nuutila, P.; Roden, M.; Hwa, A.; Bonadonna, R.; Gotthardt, M. In vivo imaging of beta cells with radiotracers: State of the art, prospects and recommendations for development and use. Diabetologia 2016, 59, 1340-1349. [CrossRef]

36. Cheung, P.; Zhang, B.; Puuvuori, E.; Estrada, S.; Amin, M.A.; Ye, S.; Korsgren, O.; Odell, L.R.; Eriksson, J.; Eriksson, O. Pet imaging of gpr44 by antagonist ${ }^{11}$ c]mk-7246 in pigs. Biomedicines 2021, 9, 434. [CrossRef]

37. Tomas, A.; Jones, B.; Leech, C. New Insights into Beta-Cell GLP-1 Receptor and cAMP Signaling. J. Mol. Biol. 2020, 432, 1347-1366. [CrossRef]

38. Lee, Y.S.; Lee, C.; Choung, J.S.; Jung, H.S.; Jun, H.S. Glucagon-like peptide 1 increases $\beta$-cell regeneration by promoting $\alpha$ - to $\beta$-cell transdifferentiation. Diabetes 2018, 67, 2601-2614. [CrossRef] 
39. Tornehave, D.; Kristensen, P.; Rømer, J.; Knudsen, L.B.; Heller, R.S. Expression of the GLP-1 receptor in mouse, rat, and human pancreas. J. Histochem. Cytochem. 2008, 56, 841-851. [CrossRef]

40. Pyke, C.; Heller, R.S.; Kirk, R.K.; Ørskov, C.; Reedtz-Runge, S.; Kaastrup, P.; Hvelplund, A.; Bardram, L.; Calatayud, D.; Knudsen, L.B. GLP-1 receptor localization in monkey and human tissue: Novel distribution revealed with extensively validated monoclonal antibody. Endocrinology 2014, 155, 1280-1290. [CrossRef]

41. Drucker, D.J.; Nauck, M.A. The incretin system: Glucagon-like peptide-1 receptor agonists and dipeptidyl peptidase-4 inhibitors in type 2 diabetes. Lancet 2006, 368, 1696-1705. [CrossRef]

42. Boss, M.; Buitinga, M.; Jansen, T.J.P.; Brom, M.; Visser, E.P.; Gotthardt, M. PET-based human dosimetry of 68Ga-NODAGAexendin-4, a tracer for $\beta$-cell imaging. J. Nucl. Med. 2020, 61, 112-116. [CrossRef]

43. Selvaraju, R.K.; Velikyan, I.; Johansson, L.; Wu, Z.; Todorov, I.; Shively, J.; Kandeel, F.; Korsgren, O.; Eriksson, O. In vivo imaging of the glucagonlike peptide 1 receptor in the pancreas with 68Ga-labeled DO3A-exendin-4. J. Nucl. Med. 2013, 54, 1458-1463. [CrossRef]

44. Eriksson, O.; Velikyan, I.; Haack, T.; Bossart, M.; Laitinen, I.; Larsen, P.J.; Berglund, J.E.; Antoni, G.; Johansson, L.; Pierrou, S.; et al. Glucagon Like Peptide-1 receptor imaging in individuals with Type 2 Diabetes. J. Nucl. Med. 2021. [CrossRef]

45. Wang, Y.; Lim, K.; Normandin, M.; Zhao, X.; Cline, G.W.; Ding, Y.S. Synthesis and evaluation of $\left[{ }^{18}\right.$ F] exendin (9-39) as a potential biomarker to measure pancreatic $\beta$-cell mass. Nucl. Med. Biol. 2012, 39, 167-176. [CrossRef] [PubMed]

46. Kimura, H.; Ogawa, Y.; Fujimoto, H.; Mukai, E.; Kawashima, H.; Arimitsu, K.; Toyoda, K.; Fujita, N.; Yagi, Y.; Hamamatsu, K.; et al. Evaluation of 18F-labeled exendin(9-39) derivatives targeting glucagon-like peptide-1 receptor for pancreatic $\beta$-cell imaging. Bioorg. Med. Chem. 2018, 26, 463-469. [CrossRef]

47. Fujimoto, H.; Fujita, N.; Hamamatsu, K.; Murakami, T.; Nakamoto, Y.; Saga, T.; Ishimori, T.; Shimizu, Y.; Watanabe, H.; Sano, K.; et al. First-in-Human Evaluation of Positron Emission Tomography/Computed Tomography With $\left[{ }^{18}\right.$ F]FB(ePEG12)12-Exendin-4: A Phase 1 Clinical Study Targeting GLP-1 Receptor Expression Cells in Pancreas. Front. Endocrinol. (Lausanne) 2021, 12, 1-8. [CrossRef]

48. Murakami, T.; Fujimoto, H.; Hamamatsu, K.; Yamauchi, Y.; Kodama, Y.; Fujita, N.; Fujikura, J.; Shimizu, Y.; Nakamoto, Y.; Kimura, H.; et al. Distinctive detection of insulinoma using [ $\left.{ }^{18} \mathrm{~F}\right] \mathrm{FB}(\mathrm{ePEG} 12) 12-e x e n d i n-4$ PET/CT. Sci. Rep. 2021, 11, 1-12. [CrossRef]

49. Jansen, T.J.P.; van Lith, S.A.M.; Boss, M.; Brom, M.; Joosten, L.; Béhé, M.; Buitinga, M.; Gotthardt, M. Exendin-4 analogs in insulinoma theranostics. J. Label. Compd. Radiopharm. 2019, 62, 656-672. [CrossRef]

50. Doyle, M.E.; Egan, J.M. Mechanisms of action of glucagon-like peptide 1 in the pancreas. Pharmacol. Ther. 2007, 113, 546-593. [CrossRef] [PubMed]

51. Xu, G.; Kaneto, H.; Laybutt, D.R.; Duvivier-Kali, V.F.; Trivedi, N.; Suzuma, K.; King, G.L.; Weir, G.C.; Bonner-Weir, S. Downregulation of GLP-1 and GIP receptor expression by hyperglycemia: Possible contribution to impaired incretin effects in diabetes. Diabetes 2007, 56, 1551-1558. [CrossRef] [PubMed]

52. Zhang, Y.; Parajuli, K.R.; Fava, G.E.; Gupta, R.; Xu, W.; Nguyen, L.U.; Zakaria, A.F.; Fonseca, V.A.; Wang, H.; Mauvais-Jarvis, F.; et al. GLP-1 receptor in pancreatic A-cells regulates glucagon secretion in a glucose-dependent bidirectional manner. Diabetes 2019, 68, 34-44. [CrossRef] [PubMed]

53. Khera, E.; Zhang, L.; Roberts, S.; Nessler, I.; Sandoval, D.; Reiner, T.; Thurber, G.M. Blocking of glucagonlike peptide-1 receptors in the exocrine pancreas improves specificity for B-cells in a mouse model of type 1 diabetes. J. Nucl. Med. 2019, 60, 1635-1641. [CrossRef]

54. Gotthardt, M.; Joosten, L.; Jansen, T.J.P.; Brom, M.; Boss, M.; Willekens, S.M.A. From Mice to Humans: The Exocrine Pancreas Does Not Matter in Human GLP-1 Receptor Imaging. J. Nucl. Med. 2021, 62, 745. [CrossRef]

55. Eriksson, O.; Rosenström, U.; Selvaraju, R.K.; Eriksson, B.; Velikyan, I. Species differences in pancreatic binding of DO3A-VSCys40-Exendin4. Acta Diabetol. 2017, 54, 1039-1045. [CrossRef] [PubMed]

56. Erickson, J.D.; Varoqui, H. Molecular analysis of vesicular amine transporter function and targeting to secretory organelles. FASEB J. 2000, 14, 2450-2458. [CrossRef]

57. Anlauf, M.; Eissele, R.; Schäfer, M.K.H.; Eiden, L.E.; Arnold, R.; Pauser, U.; Klöppel, G.; Weihe, E. Expression of the two isoforms of the vesicular monoamine transporter (VMAT1 and VMAT2) in the endocrine pancreas and pancreatic endocrine tumors. J. Histochem. Cytochem. 2003, 51, 1027-1040. [CrossRef]

58. Yero, T.; Rey, J.A. Tetrabenazine (Xenazine), An FDA-Approved Treatment Option For Huntington's Disease-Related Chorea. Pharm. Ther. 2008, 33, 690-694.

59. Normandin, M.D.; Petersen, K.F.; Ding, Y.S.; Lin, S.F.; Naik, S.; Fowles, K.; Skovronsky, D.M.; Herold, K.C.; McCarthy, T.J.; Calle, R.A.; et al. In vivo imaging of endogenous pancreatic $\beta$-cell mass in healthy and type 1 diabetic subjects using 18F-fluoropropyldihydrotetrabenazine and PET. J. Nucl. Med. 2012, 53, 908-916. [CrossRef]

60. Cline, G.W.; Naganawa, M.; Chen, L.; Chidsey, K.; Carvajal-Gonzalez, S.; Pawlak, S.; Rossulek, M.; Zhang, Y.; Bini, J.; McCarthy, T.J.; et al. Decreased VMAT2 in the pancreas of humans with type 2 diabetes mellitus measured in vivo by PET imaging. Diabetologia 2018, 61, 2598-2607. [CrossRef] [PubMed]

61. Saisho, Y.; Harris, P.E.; Butler, A.E.; Galasso, R.; Gurlo, T.; Rizza, R.A.; Butler, P.C. Relationship between pancreatic vesicular monoamine transporter 2 (VMAT2) and insulin expression in human pancreas. J. Mol. Histol. 2008, 39, 543-551. [CrossRef]

62. Freeby, M.; Ichise, M.; Harris, P.E. Vesicular monoamine transporter, type 2 (vmat2) expression as it compares to insulin and pancreatic polypeptide in the head, body and tail of the human pancreas. Islets 2012, 4, 393-397. [CrossRef] 
63. Naganawa, M.; Lim, K.; Nabulsi, N.B.; Lin, S.F.; Labaree, D.; Ropchan, J.; Herold, K.C.; Huang, Y.; Harris, P.; Ichise, M.; et al. Evaluation of Pancreatic VMAT2 Binding with Active and Inactive Enantiomers of $\left[{ }^{18} \mathrm{~F}\right] \mathrm{FP}-\mathrm{DTBZ}$ in Healthy Subjects and Patients with Type 1 Diabetes. Mol. Imaging Biol. 2018, 20, 835-845. [CrossRef]

64. Bini, J.; Naganawa, M.; Nabulsi, N.; Huang, Y.; Ropchan, J.; Lim, K.; Najafzadeh, S.; Herold, K.C.; Cline, G.W.; Carson, R.E. Evaluation of PET brain radioligands for imaging pancreatic b-cell mass: Potential utility of 11C-(1)-PHNO. J. Nucl. Med. 2018, 59, 1249-1254. [CrossRef]

65. Bini, J.; Sanchez-Rangel, E.; Gallezot, J.D.; Naganawa, M.; Nabulsi, N.; Lim, K.; Najafzadeh, S.; Shirali, A.; Ropchan, J.; Matuskey, D.; et al. PET imaging of pancreatic dopamine D2 and D3 receptor density with 11C-(1)-PHNO in type 1 diabetes. J. Nucl. Med. 2020, 61, 570-576. [CrossRef] [PubMed]

66. Lindskog, C.; Korsgren, O.; Pontén, F.; Eriksson, J.W.; Johansson, L.; Danielsson, A. Novel pancreatic beta cell-specific proteins: Antibody-based proteomics for identification of new biomarker candidates. J. Proteomics 2012, 75, 2611-2620. [CrossRef] [PubMed]

67. Hellström-Lindahl, E.; Danielsson, A.; Ponten, F.; Czernichow, P.; Korsgren, O.; Johansson, L.; Eriksson, O. GPR44 is a pancreatic protein restricted to the human beta cell. Acta Diabetol. 2016, 53, 413-421. [CrossRef]

68. Skrtic, S.; Tyrberg, B.; Broberg, M.; Ericsson, H.; Schnecke, V.; Kjaer, M.; Hompesch, M.; Andersson, E.M.; Ryberg, E.; Aivazidis, A.; et al. Exploring the insulin secretory properties of the PGD 2-GPR44/DP2 axis in vitro and in a randomized phase-1 trial of type 2 diabetes patients. PLOS ONE 2018, 13, e0208998. [CrossRef]

69. Abadpour, S.; Tyrberg, B.; Schive, S.W.; Huldt, C.W.; Gennemark, P.; Ryberg, E.; Rydén-Bergsten, T.; Smith, D.M.; Korsgren, O.; Skrtic, S.; et al. Inhibition of the prostaglandin D2-GPR44/DP2 axis improves human islet survival and function. Diabetologia 2020, 63, 1355-1367. [CrossRef] [PubMed]

70. Xue, L.; Gyles, S.L.; Wettey, F.R.; Gazi, L.; Townsend, E.; Hunter, M.G.; Pettipher, R. Prostaglandin D 2 Causes Preferential Induction of Proinflammatory Th2 Cytokine Production through an Action on Chemoattractant Receptor-Like Molecule Expressed on Th2 Cells. J. Immunol. 2005, 175, 6531-6536. [CrossRef]

71. Kupczyk, M.; Kuna, P. Targeting the PGD2/CRTH2/DP1 Signaling Pathway in Asthma and Allergic Disease: Current Status and Future Perspectives. Drugs 2017, 77, 1281-1294. [CrossRef]

72. Jahan, M.; Johnström, P.; Selvaraju, R.K.; Svedberg, M.; Winzell, M.S.; Bernström, J.; Kingston, L.; Schou, M.; Jia, Z.; Skrtic, S.; et al . The development of a GPR44 targeting radioligand $\left[{ }^{11} \mathrm{C}\right] \mathrm{AZ} 12204657$ for in vivo assessment of beta cell mass. EJNMMI Res. 2018, 8, 1-14. [CrossRef] [PubMed]

73. Eriksson, O.; Johnström, P.; Cselenyi, Z.; Jahan, M.; Selvaraju, R.K.; Jensen-Waern, M.; Takano, A.; Winzell, M.S.; Halldin, C.; Skrtic, S.; et al. In vivo visualization of b-cells by targeting of GPR44. Diabetes 2018, 67, 182-192. [CrossRef]

74. Gallant, M.; Beaulieu, C.; Berthelette, C.; Colucci, J.; Crackower, M.A.; Dalton, C.; Denis, D.; Ducharme, Y.; Friesen, R.W.; Guay, D.; et al. Discovery of MK-7246, a selective CRTH2 antagonist for the treatment of respiratory diseases. Bioorg. Med. Chem. Lett. 2011, 21, 288-293. [CrossRef] [PubMed]

75. Gervais, F.G.; Sawyer, N.; Stocco, R.; Hamel, M.; Krawczyk, C.; Sillaots, S.; Denis, D.; Wong, E.; Wang, Z.; Gallant, M.; et al. Pharmacological characterization of MK-7246, a potent and selective CRTH2 (chemoattractant receptor-homologous molecule expressed on T-helper type 2 cells) antagonist. Mol. Pharmacol. 2011, 79, 69-76. [CrossRef]

76. Eriksson, J.; Roy, T.; Sawadjoon, S.; Bachmann, K.; Sköld, C.; Larhed, M.; Weis, J.; Selvaraju, R.K.; Korsgren, O.; Eriksson, O.; et al. Synthesis and preclinical evaluation of the CRTH2 antagonist $\left[{ }^{11} \mathrm{C}\right] \mathrm{MK}-7246$ as a novel PET tracer and potential surrogate marker for pancreatic beta-cell mass. Nucl. Med. Biol. 2019, 71, 1-10. [CrossRef]

77. Guiot, Y.; Stevens, M.; Marhfour, I.; Stiernet, P.; Mikhailov, M.; Ashcroft, S.J.H.; Rahier, J.; Henquin, J.C.; Sempoux, C. Morphological localisation of sulfonylurea receptor 1 in endocrine cells of human, mouse and rat pancreas. Diabetologia 2007, 50, 1889-1899. [CrossRef]

78. Kaubisch, N.; Hammer, R.; Angeli, D.; Offord, R.E. Specific receptors for sulfonylureas in brain and in a B-cell tumor of the rat. Biochem. Pharmacol. 1982, 31, 1171-1174. [CrossRef]

79. Inagaki, N.; Gonoi, T.; Clement IV, J.P.; Namba, N.; Inazawa, J.; Gonzalez, G.; Aguilar-Bryan, L.; Seino, S.; Bryan, J. Reconstitution of IKATP: An inward rectifier subunit plus the sulfonylurea receptor. Science 1995, 270, 1166-1170. [CrossRef]

80. Koster, J.C.; Permutt, M.A.; Nichols, C.G. Diabetes and insulin secretion: The ATP-sensitive K+ channel (KATP) connection. Diabetes 2005, 54, 3065-3072. [CrossRef] [PubMed]

81. Mikhailov, M.V.; Mikhailova, E.A.; Ashcroft, S.J.H. Investigation of the molecular assembly of $\beta$-cell K(ATP) channels. FEBS Lett. 2000, 482, 59-64. [CrossRef]

82. Nakamura, Y.; Bryan, J. Targeting SUR1/Abcc8-type neuroendocrine KATP channels in pancreatic islet cells. PLoS ONE 2014, 9, e91525. [CrossRef]

83. Hansen, J. Towards Selective Kir6.2/SUR1 Potassium Channel Openers, Medicinal Chemistry and Therapeutic Perspectives. Curr. Med. Chem. 2006, 13, 361-376. [CrossRef]

84. Lamos, E.M.; Stein, S.A.; Davis, S.N. Combination of glibenclamide-metformin $\mathrm{HCl}$ for the treatment of type 2 diabetes mellitus. Expert Opin. Pharmacother. 2012, 13, 2545-2554. [CrossRef]

85. Ladrière, L.; Malaisse-Lagae, F.; Malaisse, W.J. Uptake of tritiated glibenclamide by endocrine and exocrine pancreas. Endocrine 2000, 12, 329-332. [CrossRef]

86. Carpentier, J.L.; Sawano, F.; Ravazzola, M.; Malaisse, W.J. Internalization of 3H-glibenclamide in pancreatic islet cells. Diabetologia 1986, 29, 259-261. [CrossRef] 
87. Schneider, S.; Feilen, P.J.; Schreckenberger, M.; Schwanstecher, M.; Schwanstecher, C.; Buchholz, H.G.; Thews, O.; Oberholzer, K.; Korobeynikov, A.; Bauman, A.; et al. In vitro and in vivo evaluation of novel glibenclamide derivatives as imaging agents for the non-invasive assessment of the pancreatic islet cell mass in animals and humans. Exp. Clin. Endocrinol. Diabetes 2005, 113, 388-395. [CrossRef]

88. Schneider, S.; Ueberberg, S.; Korobeynikov, A.; Schechinger, W.; Schwanstecher, C.; Schwanstecher, M.; Klein, H.H.; Schirrmacher, E. Synthesis and evaluation of a glibenclamide glucose-conjugate: A potential new lead compound for substituted glibenclamide derivatives as islet imaging agents. Regul. Pept. 2007, 139, 122-127. [CrossRef] [PubMed]

89. Ohta, Y.; Kosaka, Y.; Kishimoto, N.; Wang, J.; Smith, S.B.; Honig, G.; Kim, H.; Gasa, R.M.; Neubauer, N.; Liou, A.; et al. Convergence of the insulin and serotonin programs in the pancreatic $\beta$-cell. Diabetes 2011, 60, 3208-3216. [CrossRef]

90. Almaça, J.; Molina, J.; Menegaz, D.; Pronin, A.N.; Tamayo, A.; Slepak, V.; Berggren, P.O.; Caicedo, A. Human Beta Cells Produce and Release Serotonin to Inhibit Glucagon Secretion from Alpha Cells. Cell Rep. 2016, 17, 3281-3291. [CrossRef] [PubMed]

91. Paulmann, N.; Grohmann, M.; Voigt, J.P.; Bert, B.; Vowinckel, J.; Bader, M.; Skelin, M.; Jevšek, M.; Fink, H.; Rupnik, M.; et al. Intracellular serotonin modulates insulin secretion from pancreatic $\beta$-cells by protein serotonylation. PLoS Biol. 2009, 7, e1000229. [CrossRef]

92. Eriksson, O.; Selvaraju, R.K.; Johansson, L.; Eriksson, J.W.; Sundin, A.; Antoni, G.; Sörensen, J.; Eriksson, B.; Korsgren, O. Quantitative imaging of serotonergic biosynthesis and degradation in the endocrine pancreas. J. Nucl. Med. 2014, 55, 460-465. [CrossRef]

93. Di Gialleonardo, V.; Signore, A.; Scheerstra, E.A.; Visser, A.K.D.; Van Waarde, A.; Dierckx, R.A.J.O.; De Vries, E.F.J. ${ }^{11}$ Chydroxytryptophan uptake and metabolism in endocrine and exocrine pancreas. J. Nucl. Med. 2012, 53, 1755-1763. [CrossRef] [PubMed]

94. Eriksson, O.; Espes, D.; Selvaraju, R.K.; Jansson, E.; Antoni, G.; Sorensen, J.; Lubberink, M.; Biglarnia, A.R.; Eriksson, J.W.; Sundin, A.; et al. Positron emission tomography ligand $\left[{ }^{11} \mathrm{C}\right] 5$-hydroxy-Tryptophan can be used as a surrogate marker for the human endocrine pancreas. Diabetes 2014, 63, 3428-3437. [CrossRef] [PubMed]

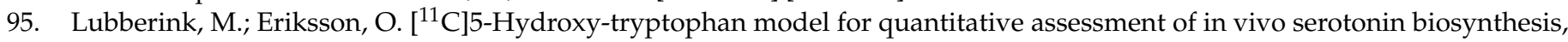
retention and degradation in the endocrine pancreas. Am. J. Nucl. Med. Mol. Imaging 2020, 10, 226-234. [PubMed]

96. Espes, D.; Carlsson, P.O.; Selvaraju, R.K.; Rosestedt, M.; Cheung, P.; Ahlström, H.; Korsgren, O.; Eriksson, O. Longitudinal Assessment of 11C-5-Hydroxytryptophan Uptake in Pancreas After Debut of Type 1 Diabetes. Diabetes 2021, 70, $966-975$. [CrossRef] [PubMed]

97. Eizirik, D.L.; Sammeth, M.; Bouckenooghe, T.; Bottu, G.; Sisino, G.; Igoillo-Esteve, M.; Ortis, F.; Santin, I.; Colli, M.L.; Barthson, J.; et al. The human pancreatic islet transcriptome: Expression of candidate genes for type 1 diabetes and the impact of pro-inflammatory cytokines. PLoS Genet. 2012, 8, e1002552. [CrossRef] [PubMed]

98. Balhuizen, A.; Massa, S.; Mathijs, I.; Turatsinze, J.V.; De Vos, J.; Demine, S.; Xavier, C.; Villate, O.; Millard, I.; Egrise, D.; et al. A nanobody-based tracer targeting DPP6 for non-invasive imaging of human pancreatic endocrine cells. Sci. Rep. 2017, 7, 15130. [CrossRef]

99. Demine, S.; Garcia Ribeiro, R.; Thevenet, J.; Marselli, L.; Marchetti, P.; Pattou, F.; Kerr-Conte, J.; Devoogdt, N.; Eizirik, D.L. A nanobody-based nuclear imaging tracer targeting dipeptidyl peptidase 6 to determine the mass of human beta cell grafts in mice. Diabetologia 2020, 63, 825-836. [CrossRef] [PubMed]

100. Brissova, M.; Haliyur, R.; Saunders, D.; Shrestha, S.; Dai, C.; Blodgett, D.M.; Bottino, R.; Campbell-Thompson, M.; Aramandla, R.; Poffenberger, G.; et al. $\alpha$ Cell Function and Gene Expression Are Compromised in Type 1 Diabetes. Cell Rep. 2018, 22, $2667-2676$. [CrossRef]

101. Alavi, A.; Werner, T.J. Futility of attempts to detect and quantify beta cells by PET imaging in the pancreas: Why it is time to abandon the approach. Diabetologia 2018, 61, 2512-2515. [CrossRef] [PubMed]

102. Gotthardt, M.; Eizirik, D.L.; Aanstoot, H.J.; Korsgren, O.; Mul, D.; Martin, F.; Boss, M.; Jansen, T.J.P.; van Lith, S.A.M.; Buitinga, M.; et al. Detection and quantification of beta cells by PET imaging: Why clinical implementation has never been closer. Diabetologia 2018, 61, 2516-2519. [CrossRef] [PubMed] 